\title{
CHOLESTEROL LEVELS IN PANIC DISORDER, GENERALIZED ANXIETY DISORDER AND MAJOR DEPRESSION
}

\author{
ACIOLY L.T. LACERDA*, DORGIVAL CAETANO**, SHEILA C. CAETANO***
}

\begin{abstract}
Serum plasma total cholesterol levels were measured in 85 male or female outpatients with panic disorder ( $\mathrm{PD} ; \mathrm{N}=41$ ), generalized anxiety disorder ( $\mathrm{GAD} ; \mathrm{N}=23$ ) and major depression (MD; $\mathrm{N}=21$ ) according to DSM-IV criteria. All the patients had a mean cholesterol level within the normal range; males $(\mathrm{N}=22)$ and females $(\mathrm{N}=63)$ had approximately the same serum cholesterol levels $(\mathrm{p}>.05)$. No significant differences in cholesterol levels emerged between PD, GAD and MD patient groups. Both female PD and female GAD subjects had a mean cholesterol level similar to their male counterparts ( $p>.05$ ). It is concluded that both Hayward and colleagues and Bajwa et al. findings could not be replicated by our study.
\end{abstract}

KEY WORDS: cholesterol, generalized anxiety disorder, major depression, panic disorder.

\begin{abstract}
Níveis de colesterol no transtorno de pânico, transtorno de ansiedade generalizada e depressão maior
RESUMO - Foram medidos os níveis plasmáticos de colesterol total em 85 pacientes ambulatoriais com transtorno de pânico (TP; $N=41$ ), transtorno de ansiedade generalizada (TAG; $N=23$ ) e depressão maior ( $\mathrm{DM} ; \mathrm{N}=21$ ), diagnosticados de acordo com os critérios do DSM-IV. O grupo de pacientes apresentou média do nível de colesterol dentro da faixa normal; homens $(\mathrm{N}=22)$ e mulheres $(\mathrm{N}=63)$ tiveram aproximadamente os mesmos níveis séricos de colesterol $(\mathrm{p}>0,05)$. Não foram observadas diferenças nos níveis de colesterol entre os grupos de pacientes com TP, TAG e DM. Mulheres com TP e as com TAG apresentaram média dos níveis de colesterol semelhante aos seus pares masculinos ( $p>0,05)$. Conclui-se que os resultados obtidos por Hayward et al. e por Bajwa et al. não foram replicados neste estudo.
\end{abstract} pânico.

PALAVRAS-CHAVE: colesterol, transtorno de ansiedade generalizada, depressão maior, transtorno do

In a study carried out by Coryell et al. ${ }^{1}$, male patients with panic disorder (PD) exhibited excess mortality due to unnatural causes and to circulatory system disease as compared to age- and gender-specific general population figures. Similar results were reported in a 12-year follow-up of 115 outpatients with "anxiety neurosis". Again men had an excess in death which was attributed to cardiovascular disease and suicide ${ }^{2}$.

Nesse et $\mathrm{al}^{3}$ found that patients with PD had an increased adrenergic function (elevated resting heart rate, elevated levels of plasma epinephrine, cortisol and growth hormone, and mildly elevated plasma norepinephrine levels) even in the absence of panic attacks. Dimsdale and Herd ${ }^{4}$, reviewed 60 studies relating plasma lipids and emotional arousal. Most of these studies reported that cholesterol increased from 8 to $65 \%$ above baseline under stressful conditions. PD and anxious patients, at least when they are ill, have lower threshold for stimuli (environmental, emotional, etc.).

State University of Campinas (UNICAMP), Brazil: *MD, Psychiatrist of Department of Psychiatry; **MD. PhD, Full Professor of Department of Psychiatry; ***MD, Resident of Department of Psychiatry, University of São Paulo. Aceite: 19-fevereiro-2000.

Dr. Acioly Luiz Tavares de Lacerda - Rua Fernando Costa 200 - 13026-360 Campinas SP - Brasil. FAX 5519294 2034. E-mail: lacerda@mpc.com.br 
As a consequence, they feel under stress most of the time. If stressful situations are related to higher cholesterol levels, then one would expect for PD and generalized anxiety disorder (GAD) patients higher plasma cholesterol levels than that found in the general population.

In Hayward et al. study ${ }^{5}$, females (but not males) with panic disorder or agoraphobia had significantly higher than expected cholesterol values that exceeded the 75th percentile of USA references. Bajwa et al. ${ }^{6}$ compared cholesterol levels of patients with PD, major depression (MD) according to DSM-III-R, and normal controls matched for age and gender. They found that patients with PD had significantly higher serum cholesterol levels than normal controls and those with MD. Both studies hypothesized that higher cholesterol levels could be a result of noradrenergic activity, placing these patients at greater risk for the development of cardiovascular disease. That deserves further study. As in both studies PD was the only anxiety disorder included, it unclear whether these findings are specific for PD or whether they related to any anxiety disorder.

To replicate and extend these findings, we measured cholesterol levels in 3 groups of patients: $\mathrm{PD}, \mathrm{GAD}$, and MD.

\section{METHOD}

Subjects were 85 male or female outpatients free of medication, enrolled in treatment in a university hospital. After clinical examination to rule out medical conditions, the patients were diagnosed as PD, GAD, and MD, following DSM-IV criteria. No instructions to change the patients' usual dietary habits were given. Blood samples were drawn after a 12-hour fast and cholesterol serum levels were assessed by means of Chod-Top. Comorbidity with alcohol/drug abuse were excluded. Mean differences between two groups were tested by twotailed $t$-test, and for three groups by means of ANOVA.

\section{RESULTS}

Altogether the 3 groups $(\mathrm{N}=85$ : $\mathrm{PD}+\mathrm{GAD}+\mathrm{MD})$ had a mean $( \pm \mathrm{SD})$ total cholesterol level $(\mathrm{mg} / \mathrm{dl})$ of $178.3 \pm 39.0$ which lies within the normal range (Table 1$)$. Female patients $(\mathrm{N}=63)$ had a higher mean $( \pm \mathrm{SD})$ cholesterol level $(182.4 \pm 38.1)$ than males $(\mathrm{N}=22 ; 170.6 \pm 12.4)$, although they weighted $(61.8 \pm 12.1)$ less than their male counterparts $(65.4 \pm 10.1)$. These differences, however, did not reach significance ( $\mathrm{p}>.05)$.

Table 2 shows that there were 41 individuals $(33 \mathrm{~F}$ and $8 \mathrm{M})$ with $\mathrm{PD}, 23(13 \mathrm{~F}$ and $10 \mathrm{M})$ with $\mathrm{GAD}$, and $21(15 \mathrm{~F}$ and $6 \mathrm{M})$ with MD. The mean $( \pm \mathrm{SD})$ cholesterol level $(\mathrm{mg} / \mathrm{dl})$ was highest for the PD patients $(182.4 \pm 40.1)$, intermediate for GAD $(175.6 \pm 31.3)$, and lowest for $\mathrm{MD}(173.6 \pm$ 31.3), despite the fact that the latter were older. These differences, however, were not significant ( $F$ $=0.46, \mathrm{df}=2 ; \mathrm{p}=0.6$ ) and all the values lie within the normal range.

Table 1. Characteristics of the whole sample (panic disorder + generalized anxiety disorder + major depression) in terms of gender, weight, and cholesterol levels, and t-test on weight and cholesterol level by gender.

\begin{tabular}{lll}
\hline Gender & Weight $(\mathrm{Kg})$ & Cholesterol levels $(\mathrm{mg} / \mathrm{dl})$ \\
& Mean $\pm \mathrm{SD}$ & Mean \pm SD \\
\hline Female $(\mathrm{N}=63)$ & $61.8 \pm 12.1$ & $182.4 \pm 38.1$ \\
Male $(\mathrm{N}=22)$ & $65.4 \pm 10.1$ & $170.6 \pm 12.4$ \\
$\mathrm{P}$ & $\mathrm{ns}$ & $\mathrm{ns}$ \\
Female + Male $(\mathrm{N}=85)$ & $62.7 \pm 11.6$ & $178.3 \pm 39.0$ \\
\hline
\end{tabular}

ns, non-significant at $5 \%$. 
Table 2. ANOVA on cholesterol levels and age between groups of patients with panic disorder (PD), generalized anxiety disorder (GAD), major depression (MD), and t-test on cholesterol levels by sex.

\begin{tabular}{|c|c|c|c|c|c|c|}
\hline & $\begin{array}{l}\text { Patients with } \\
\mathrm{PD}(\mathrm{N}=41) \\
\text { Mean } \pm \mathrm{SD}\end{array}$ & $\begin{array}{l}\text { Patients with } \\
\text { GAD }(\mathrm{N}=23) \\
\text { Mean } \pm \mathrm{SD}\end{array}$ & $\begin{array}{l}\text { Patients with } \\
M D(N=21) \\
\text { Mean } \pm \text { SD }\end{array}$ & F & $\begin{array}{c}\text { Analysis } \\
\text { df }\end{array}$ & $\mathrm{p}$ \\
\hline Cholesterol levels (mg/dl) & $182.4 \pm 40.1$ & $175.2 \pm 31.3$ & $173.6 \pm 47.4$ & 0.46 & 2 & 0.6 \\
\hline Age & $37.4 \pm 12.9$ & $33.7 \pm 8.6$ & $40.8 \pm 14.4$ & 1.74 & 2 & 0.2 \\
\hline \multicolumn{7}{|l|}{ Cholesterol Levels (mg/dl) } \\
\hline \multicolumn{7}{|l|}{ Gender } \\
\hline Female & $183.5 \pm 35.3$ & $176.0 \pm 32.1$ & $186.3 \pm 40.4$ & & & \\
\hline Male & $180.4 \pm 48.5$ & $173.8 \pm 31.8$ & $141.8 \pm 27.1$ & & & \\
\hline $\mathrm{p}$ & ns & ns & .02 & & & \\
\hline
\end{tabular}

ns, non-significant at $5 \%$.

Patients in each group were splitted by gender. No significant difference in cholesterol levels emerged between PD female patients $(183.5 \pm 35.3)$ when compared with male patients $(180.4 \pm$ 48.5) $(\mathrm{p}=0.4)$, nor between GAD females $(176.0 \pm 32.1)$ and males $(173.8 \pm 31.8)(\mathrm{p}=0.4)$. However, female patients with MD had a significantly higher mean $( \pm$ SD) cholesterol level (186.3 $\pm 40.4)$ than their male counterparts $(141.8 \pm 27.1)(\mathrm{p}=0.02)$. ANOVA on age for the 3 groups showed no statistically significant difference: GAD patients were the youngest with a mean age (years) of $33.7 \pm 8.6$, followed by PD patients with a mean of $37.4 \pm 12.9$, and MD patients $40.8 \pm$ $14.4(\mathrm{~F}=1.74 ; \mathrm{p}=0.2)$.

The 3 groups were pooled together and a regression analysis on cholesterol (dependent variable) in relation to age was carried out. It yielded a highly significant coefficient $(F=7.7 ; p=0.007)$ which confirms findings widely reported in the literature of a strong correlation between age and cholesterol levels.

\section{DISCUSSION}

Hayward et al. ${ }^{5}$ found that female PD subjects had a higher serum cholesterol level than expected. Bajwa et al. ${ }^{6}$ reported that PD (male + female) individuals had a significantly higher serum cholesterol level than normal controls or patients with MD. These findings might suggest that in PD subjects an increased noradrenergic activity would lead to activation of the mechanism of induction of lipoprotein lipase that results in an increase of free fatty acids in the serum. High cholesterol level plus increased noradrenergic function would place these individuals at higher risk to develop cardiovascular disease. That would be in line with Coryell and colleagues' findings ${ }^{1,2}$ of excess mortality due to cardiovascular disease in males with panic or anxiety disorder. Hence, the treatment of panic or anxiety disorder would have a bearing on both increased noradrenergic activity and cholesterol level, thus reducing the risk for cardiovascular disease.

This hypothesis, however, has been challenged by Feder ${ }^{7}$ who calls attention to the fact that cholesterol levels are much strongly influenced by genetics and diet than by psychological stress. Before one dwells on theories, the findings from which they were developed should be replicated for the sake of consistency and validation. Reifman and Windle ${ }^{8}$ could not replicate Hayward et al. ${ }^{5}$ and Bajwa et al. ${ }^{6}$ studies in a male sample. In this study the authors found approximately the same cholesterol level values for panic disorder, major depression only, major depression with anxiety, and normal controls ( $\mathrm{p}>$. 40). 
Our own findings are in agreement with the latter. Both female PD and female GAD patients had mean total cholesterol levels approximately the same as their male counterparts ( $p>.05)$ (Table 2). Similar results were found for the whole sample (PD + GAD + MD) when compared male with female subjects $(\mathrm{p}>.05)$ (Table 1). In the same vein, a comparison between patient groups PD $(\mathrm{F}+\mathrm{M}), \mathrm{GAD}(\mathrm{F}+\mathrm{M})$, and $\mathrm{MD}(\mathrm{F}+\mathrm{M})$ showed no significant differences in cholesterol levels $(\mathrm{F}=$ $0.46 ; \mathrm{df}=2 ; \mathrm{p}=.0 .6)$. The only significant difference emerged on cholesterol level of female MD subjects when compared with their male counterparts $(\mathrm{p}=.02)$. A full understanding of this finding calls for further analyses of covariance controlling for age and body mass, among other co-factors.

\section{Conclusion}

Our findings did not replicate those found by Hayward et al. and by Bajwa et al. that PD subjects had a significantly higher serum cholesterol level than normal controls or patients with $\mathrm{MD}$, and are in agreement with those reported by Reifman and Windle who found no such difference between PD, major depression only, and major depression with anxiety.

\section{REFERENCES}

1. Coryell W, Noyes R, Clancy J. Excess mortality in panic disorder: a comparison with primary unipolar depression. Arch Gen Psychiatry 1982;39:701-703.

2. Coryell W, Noyes R, House JD. Mortality among outpatients with anxiety disorders. Am J Psychiatry 1986;143:508-510.

3. Nesse RM, Cameron OG, Curtis GC, McCann DS, Huber-Smith MJ. Adrenergic function in patients with panic anxiety. Arch Gen Psychiatry 1984;41:771-776.

4. Dimsdale JE, Herd JA. Variability of plasma lipids in response to emotional arousal. Psychosom Med 1982;44:413-430.

5. Hayward C, Taylor CB, Roth WT, King R, Agras WS. Plasma lipid levels in patients with panic disorder or agoraphobia. Am J Psychiatry 1989;146:917-919.

6. Bajwa WK, Asnis GM, Sanderson WC, Irfan A, Van Praag HM. High cholesterol levels in patients with panic disorder. Am J Psychiatry 1992; 149:376-378.

7. Feder R. High cholesterol levels in patients with panic disorder. Am J Psychiatry 1993;150:527.

8. Reifman A, Windle M. High cholesterol levels in patients with panic disorder. Am J Psychiatry 1993;150:527. 